\title{
PROCESSOS FORMATIVOS DE UM MÍDIA NINJA E AS NOVAS NARRATIVAS DO ATIVISMO NO CONTEXTO DA CIBERCULTURA
}

\author{
T. S. PAZ* , C. O. B. SALES, N. R. SANTOS e E. S. JUNQUEIRA \\ Universidade Federal do Ceará \\ tatianaspaz@gmail.com*
}

Artigo submetido em maio/2016 e aceito em julho/2016

DOI: $10.15628 /$ holos.2016.4552

\begin{abstract}
RESUMO
As práticas comunicacionais em rede da cibercultura proporcionam um inédito fazer político que conferem novas características ao ativismo, formando um contexto para a emergência do ciberativismo. Este artigo tem como objetivo compreender como se estruturam os processos formativos de um integrante do Mídia NINJA (MN) e suas relações com o ativismo no contexto da cibercultura. $\mathrm{O}$ estudo adotou uma abordagem de estudo de caso com perspectiva etnográfica para compreender o olhar de um fotógrafo do $\mathrm{MN}$ sobre os referidos processos e relações, evidenciadas por sua experiência nas manifestações de 2013 no Brasil. As técnicas de pesquisa utilizadas foram a entrevista semi-estruturada e a coleta de dados em redes sociais. $\mathrm{O}$ arcabouço teórico do estudo abrange as teorias sobre ciberativismo
\end{abstract}

(CASTELLS, 2013; DI FELICE, 2013; ANTOUN \& MALINI, 2013); cibercultura (LEMOS, 2010; LÉVY, 1993 e 2010) e processos formativos (LAROSSA, 2002; MACEDO, 2010; DOMINCÉ, 2006). As experiências relatadas neste trabalho pelo integrante do $\mathrm{MN}$ indicaram que seus processos formativos e sua atuação, enquanto fotógrafo e ciberativista, delineiam trajetórias marcadas pelas trocas horizontais e em rede com sujeitos diversos. Estas se estruturam para além dos ambientes formais de ensino e estão relacionadas à sua atuação política como fotógrafo em formação e ativista em rede. São processos relacionados, que sustentam o ativismo atual e nele se retroalimentam. Indicam, assim, novas formas de aprender e de atuar politicamente na contemporaneidade.

PALAVRAS-CHAVE: Processos Formativos. Ativismo; Cibercultura; Mídia NINJA.

\section{THE LEARNING PROCESSES OF A MÍDIA NINJA AND ACTIVISM NEW NARRATIVES IN THE CYBERCULTURE CONTEXT}

\begin{abstract}
Communicational practices in the cyberculture context provide an unprecedented political making that originated new features to activist narratives, forming a context for the emergence of what we have named cyberactivism. This article aims to understand how the learning processes of a member of Mídia NINJA were structured along time, from the point of view of communication and learning experiences situated in the cyberculture context. This case study with a ethnographic perspective aimed to understand the perspective of a Mídia NINJA photographer upon his work, specifically in regards of his experiences in the political events that took place in Brazil in june of 2013. Data collection instruments included semi-structured interviews and social networks
\end{abstract}

analysis. The study is based on the theories of cyberactivism (CASTELLS, 2013; DI FELICE, 2013; ANTOUN \& MALINI, 2013); cyberculture (LEMOS, 2010; LÉVY, 1993 and 2010) and learning processes (LAROSSA, 2002; MACEDO, 2010; DOMINCÉ, 2006). The experiences detailed in this paper by a member of Mídia NINJA has indicated that his training and his work, as a photographer and a cyberactivist, outline paths of a learning process marked by horizontal exchanges of experiences and networking. These processes are related and they sustain current activism and are fed by them. Therefore, they point to new ways of learning and of making political action currently.

KEYWORDS: Learning Processes. Activism, Cyberculture, Mídia NINJA. 


\section{INTRODUÇÃO}

O coletivo Narrativas Independentes, Jornalismo e Ação (Mídia NINJA) - doravante identificado como MN - assumiu, desde o ano de 2013, um espaço de visibilidade no cenário midiático pós-massivo brasileiro (LEMOS, 2010). O ano de 2013 foi marcado por protestos que ficaram conhecidos como Manifestações dos 20 centavos, Manifestações de Junho ou Jornadas de Junho. Os protestos contra o aumento das tarifas do transporte público em São Paulo se ampliaram, envolvendo diferentes cidades do Brasil.

As manifestações ganharam novos rumos com a ampliação das pautas em discussão como os gastos públicos em eventos esportivos internacionais, a má qualidade no serviço público de saúde, educação e segurança, a corrupção política, entre outros. Estas manifestações tiveram repercussão nacional e internacional e o MN protagonizou um papel relevante na transmissão dos protestos. As transmissões on-line, realizadas diretamente do interior das manifestações, tiveram audiência significativa durante a jornada de junho de 2013. O trabalho de jornalismo independente do MN gerou debates entre comunicadores, jornalistas e políticos (SAVAZONI, 2014) dado o seu ineditismo no cenário midiático e político nacional.

Fruto de uma iniciativa articulada pela rede Fora do Eixo $(\mathrm{FdE})$, numa estratégia de pósmarca ${ }^{1}$, o MN integra ações de mobilização por meio de redes sociais, produção de conteúdos para blogs e sites, registro fotográfico de ações políticas, criação e manutenção de programas de WebTV, entre outras iniciativas. O histórico do Fora do Eixo, com o desenvolvimento de suas próprias mídias, utilizando os recursos disponíveis na internet, como canal no antigo Orkut, listas de discussão, chats no MSN, e blogs na plataforma Blogger, marca esta trajetória de produção midiática independente (SAVAZONI, 2014, p. 126). O MN é "um grupo de comunicação amplo e descentralizado, a fim de explorar as possibilidades de cobertura, discussão, repercussão, remuneração e da radical liberdade de expressão que a rede oferece" (TORTURRA, 2013, on-line).

O MN se identifica como expressão do midialivrismo, ou seja, o exercício autônomo de produção midiática, e é parte de um modus operandi característico dos movimentos sociais do século XXI (SAVAZONI, 2014, p. 128). As narrativas alternativas que têm buscado retratar novos ângulos do que tem acontecido nas ruas, fora do circuito da grande imprensa, possuem suas particularidades e não se resumem a uma atividade jornalística tradicional. Elas são, para além de tudo, narrativas feitas de testemunhos, análises, replicações, comentários de sujeitos diversos. A metáfora do MN é, para Malini, a generalização da capacidade coletiva em contar - de modo multimídia - as histórias de rua e amplificá-las pela rede densa de perfis nas redes sociais (IHU, 2013).

O MN constrói coletivamente uma cobertura dos acontecimentos numa perspectiva de dentro das próprias manifestações, fazendo o papel, muitas vezes, de sujeito dos atos, ao contrário da mídia tradicional que apenas grava com seus snipers e suas objetivas a metros de distância do fato, e ao final constroem narrativas editadas do acontecimento que podem ser tendenciosas (VASQUES, 2014).

\footnotetext{
${ }^{1}$ Estratégia criada pelo $\mathrm{FdE}$, em seu 4을 Congresso, com objetivo de que as iniciativas fomentadas pelo coletivo pudessem dar origem a redes autônomas (SAVAZONI, 2014).
} 
Este trabalho buscou compreender elementos do processo formativo dos ativistas e da construção dessas novas narrativas. Neste artigo o foco da análise centrou-se sobre a trajetória formativa de um fotógrafo do coletivo Mídia NINJA (MN), visto que as imagens têm recebido cada vez mais destaque nas narrativas midiáticas contemporâneas, e suas ações ativistas.

Nesta perspectiva, este artigo detalhou como se estruturam as práticas formativas e o ativismo de um Mídia NINJA com destaque para as trocas comunicacionais situadas no contexto da cibercultura. Para isso, realizamos um estudo de caso (YIN, 2005), em que foram delineadas e analisadas etapas da formação de um fotógrafo integrante da rede NINJA, notadamente sua experiência nas manifestações de 2013. Os dados foram coletados através de entrevistas semiestruturadas, principal técnica adotada nesta pesquisa, além de documentação de interações online direcionadas a narrativas do $\mathrm{MN}$ em que se destacavam fotografias do referido ativista.

\section{ATIVISMO EM TEMPOS DE CIBERCULTURA}

As ações desenvolvidas pelo $\mathrm{MN}$ estão inseridas em um contexto de mobilização na Internet, de modo geral e, em especial, nas redes sociais, que têm sido chamadas de ciberativismo ou net-ativismo. Esta mobilização faz ressoar características das lutas dos movimentos sociais que são, tradicionalmente, ações coletivas urbanas, de setores da sociedade ou organizações sociais com objetivos libertários e de mudança no quadro social (CARDOSO, 2008).

O MN pode, deste modo, ser visto como exemplo de prática ciberativista, porque articula novas formas do movimento social, questionando lugares estabelecidos de poder, ajudando a construir uma nova narrativa das reivindicações urbanas. Este novo contexto se tornou espaço de apropriações culturais, educacionais e políticas que mobilizam cenas cotidianas que ocupam outro espaço, um híbrido entre o urbano e o ciberespaço. Trazem, ainda, as marcas de características identificadas por Castells nesses movimentos:

[...] não precisam de uma liderança formal, de um centro de comando ou de controle, nem de uma organização vertical, para passar informações ou instruções. Essa estrutura descentralizada maximiza as chances de participação no movimento, já que ele é constituído de redes abertas, sem fronteiras definidas, sempre se reconfigurando segundo o nível de envolvimento da população em geral. (CASTELLS, 2013, p.129)

Ainda segundo este autor, a Internet propicia meios para que esses movimentos, sem liderança específico, possam deliberar, coordenar ações e sobreviver às tentativas de repressão. São grupos ditos sem comando, porque a comunicação em rede permite uma ação sem centro de controle, uma vez que uma ideia é lançada, a comunicação multidirecional, interativa e sem fio pode levá-la para qualquer direção, independente da coordenação de um único condutor (CASTELLS, 2013). Deste modo, é, principalmente, a Internet, com a comunicação em rede, o meio que favorece novos agrupamentos em torno de uma mesma luta e ideal, "certos tipos de organização, formas de articular ações e de se fazer política que não existiam antes" (MACHADO, 2007, p. 277).

Este novo modo de fazer política está intimamente relacionado às práticas comunicacionais da cibercultura, que permitiram, também, mudanças significativas nas relações sociais através da modificação paradigmática dos processos de interlocução que deixam de funcionar num fluxo 
unidirecional e passam a se organizar no modo todos-todos (LEMOS, 2010), em que não se depende de um pólo transmissor de informação, já que qualquer sujeito pode interagir sendo autor e coautor de conteúdos.

Assim, tratar das tecnologias da cibercultura é saber que esta se constituiu através de uma rede de comunicação física que liga os diferentes praticantes culturais, nela imersos, e possibilitou diferentes proposições socioculturais. O lugar onde essas teias comunicacionais se tecem é no ciberespaço e, neste trabalho, o compreendemos

como um espaço social constituído simultaneamente pelas redes sociais que estabelecem culturas locais em seu interior e pelas redes técnicas que possibilitam essas conexões, é um lócus conveniente para a reflexão sobre a relação entre cultura e tecnologia. Essas redes técnicas, por sua vez, são o resultado do desenvolvimento e configuração de inúmeras diferentes tecnologias, processo que, naturalmente, é intensamente social em sua própria natureza. (GUIMARÃES JR., 2010, p. 47)

Portanto, no ciberespaço, a cultura hacker, própria da cibercultura, também caracteriza esses movimentos sociais do século XXI. Entre os elementos da cultura hacker, figuram a liberdade, a criatividade e a autoria (HIMANEN, 2001; CASTELLS, 2013). Os hackeadores fazem da rede "um dispositivo de conversação e relações sociais comunitárias, onde cada um tem sua própria voz sem precisar passar pela intermediação de instituições e discursos oficiais ou comerciais" (MALINI e ANTOUN, 2013, p.18). Assim, podem se constituir como sujeitos e autores do seu processo de construção de conhecimento de forma autônoma.

O paradigma comunicacional tem mudado com o avanço das Tecnologias da Informação e Comunicação (TIC). A separação entre emissor e receptor ganhou novas configurações com a emergência do ciberespaço, possibilitando ao receptor novas formas de agência e co-construção da mensagem, através das interfaces autorais disponíveis em rede. A crescente digitalização das informações e a pontencialização das capacidades cognitivas do ser humano (LÉVY, 1993) trouxeram mudanças para os processos de criatividade e autoria, e este contexto possibilitou a renovação das narrativas que circulam na rede. No ambiente de excesso de informações circulantes no ciberespaço, nem todos que falam são realmente ouvidos. Todos podem se expressar, porém somente alguns atores se destacam. É o caso dos ciberativistas. O MN tem sido uma dessas vozes que se destaca e se faz ouvir, e que se constitui na construção coletiva dos seus integrantes e dos muitos que viralizam ${ }^{2}$ seus conteúdos na rede. Essas novas narrativas vão se articulando a partir de outros paradigmas comunicacionais, abrangendo também o próprio processo de formação do NINJA, como será detalhado a seguir.

\section{PROCESSOS FORMATIVOS E NOVAS NARRATIVAS}

O fenômeno de viralização de conteúdos (textos, fotos, vídeos, áudios e links de transmissões ao vivo) produzidos pelos coletivos midiáticos, como o $\mathrm{MN}$, no contexto do ciberativismo, tem sido denominado espalhamento (BITTENCOURT, 2015). A possibilidade de não só criar, como espalhar conteúdos articula e dissemina novas formas de mediação da informação.

\footnotetext{
${ }^{2}$ Termo utilizado para designar o processo de difusão rápida de uma informação, como um efeito viral.
} 
As práticas de espalhamento vivenciadas por estes atores constroem narrativas relacionadas a diferentes campos da vida política e social e têm o potencial de estimular processos formativos.

Compreende-se neste trabalho que processos formativos são construídos por diferentes experiências de vida que não estão restritas aos espaços formais de educação. Segundo Freire, "transformar a experiência educativa em puro treinamento técnico é amesquinhar o que existe de fundamentalmente humano no exercício educativo: seu caráter formador" (FREIRE, 1977, p.33). De acordo com Macedo (2010), toda formação implica numa vida de objetivos e responsabilidades existenciais e sociais. Referindo-se a uma "aprendizagem que forma", Macedo (2014) articula que

o sujeito busca, e é desafiado a buscar, compreender a realidade em que vive e a si, através da sua capacidade percepto-cognitiva e de interação estruturantes, (nem sempre conscientes), mediadas por suas intenções, interesses, desejos e escolhas, modificando, portanto, seu meio e a si próprio (toda aprendizagem envolve mudanças, deslocamentos, retomadas, ressignificações e possibilidade de rupturas) (s/p)

Nesse sentido, compreende-se que a experiência é um dos elementos centrais nos processos formativos (BONDÍA, 2002; MACEDO, 2010; DOMINCÉ, 2006). Essa perspectiva experencial, articulada por Bondía (2002), destaca que a formação é um fenômeno inerente ao sujeito e tem a capacidade de transformá-lo. Segundo o autor, "a experiência é o que nos passa, o que nos acontece, o que nos toca" (p.21) e o saber da experiência se dá, portanto, na relação entre o conhecimento e a vida humana. Bondía (2002) ressalta ainda que esse saber "somente tem sentido no modo como configura uma personalidade, um caráter, uma sensibilidade ou, em definitivo, uma forma humana singular de estar no mundo, que é por sua vez uma ética (um modo de conduzir-se) e uma estética (um estilo)" (p.27).

Os processos formativos que abrangem esferas das identidades dos sujeitos e objetivam transformar os contextos em que atuam, situam-se na especificidade do ativismo do $\mathrm{MN}$, em trocas comunicativas que articulam uma "nova narrativa" (NASSIF, 2013) que mobiliza princípios éticos e estéticos, dentre outros. Ou seja, operam e expressam uma maneira diferente de pensar, entender e explicar os fenômenos no contexto do ativismo atual através de uma distinta produção midiática em rede. Para os ativistas do coletivo, a tradicional forma de publicizar os acontecimentos é fragmentada e baseada em posições ideológicas, partidos políticos, formas de fazer jornalismo massivo, modos de produção industriais e alienantes.

A perspectiva da nova narrativa "promove um rompimento com tais formas de compartimentalização e é um estímulo a toda forma de trabalho coletivo, em rede" (idem, 2013, $s / p)$. Esta nova narrativa surge como um discurso "fora do lugar" (não se origina da mídia de massa, do partido político, da escola) e coloca em cena novos mediadores, não tradicionais, novos atores do discurso ou produtores de cultura (BENTES, 2009) que questionam narrativas tradicionais totalizantes.

Esta disputa de narrativas protagonizada pelos coletivos midiáticos e estruturada nas redes e em rede proporciona aos ativistas e aos seus interlocutores um espaço formativo em que são articuladas diferentes formas de pensar os eventos sociais e políticos. A fim de compreender melhor estes processos, este trabalho propõe a análise da trajetória formativa de um Mídia NINJA, enquanto um ciberativista. 


\section{MÍDIA NINJA E CIBERATIVISMO: APONTAMENTOS SOBRE PRÁTICAS FORMATIVAS CONTEMPORÂNEAS}

Os depoimentos do fotógrafo NINJA João (nome fictício para preservar a identidade desse sujeito), revelam que sua formação de fotógrafo-ativista tem sido forjada em diferentes instâncias como na família, movimento estudantil, coletivos e na própria rede. Observou-se, a partir da fala de João, que esses campos formativos não estão desarticulados entre si, ao contrário, formam uma teia de experiências que na visão de João são fundamentais para o seu fazer ativista. No entanto, por motivos didáticos, essas instâncias foram organizadas separadamente.

\subsection{Família}

João explicou que o caráter político e comunicacional do seu ativismo começou a se desenvolver no seio das suas vivências familiares. Ele possui uma história de vida marcada pela formação política e muito cedo descobriu na arte da fotografia a possibilidade de construir narrativas, e em certo momento foi impelido a unir essas duas facetas.

Desde a infância, João teve contato com a fotografia. Nos seus relatos, afirmou que sua mãe e irmão, apesar de não serem profissionais, fotografavam com frequência, e deles ganhou sua primeira máquina, já digital. Em casa teve acesso a livros, como os de Sebastião Salgado ${ }^{3}$, que o influenciaram, inclusive, em perceber a foto como uma narrativa, capaz de unir beleza e questões sociais e antropológicas. O contexto familiar foi formativo por proporcionar experiências lúdicas com aquela linguagem que atraía a sua atenção e desejo. Para João, aprender a manipular a imagem em softwares foi um processo vivenciado de forma autônoma. Neste processo, João já se apresentava como ator no processo de aprender o que tem sido relevante para sua trajetória enquanto ativista, como relatou:

Eu tive uma certa influência da minha família, meu irmão fotografava bastante, minha mãe fotografava bastante, ninguém era profissional assim, mas tinha uma cultura de fotografar. Desde moleque eu fui brincando assim bastante, até eu ganhar uma primeira câmara da minha família, tipo com dezesseis anos. Já era uma câmara digital, então eu nunca fotografei, quando moleque, com filme [...]. Aí eu já tinha uma coisa muito doida com imagem, com software, antes de começar a fotografar, eu já sabia tudo de photoshop, já manipulava imagem, já trabalhava com design, desde criança, assim, eu já brincava bastante com isso.

O ativismo político de João teve também origem familiar. Seus pais estavam envolvidos nos primórdios do Partido dos Trabalhadores (PT), participavam de comícios, e João os acompanhava. Quando ingressou na faculdade de design gráfico, na Universidade Federal de Santa Catarina, tinha consciência do seu interesse em trabalhar com fotojornalismo e fotodocumentarismo e que o currículo deste curso não oferecia possibilidades formativas para tal. Com isso, ele se envolveu em um processo educativo autônomo na busca pela construção de saberes em torno de seu interesse, como indica na sua fala: "Na [Universidade] Federal de Santa Catarina, eu acabei mergulhando na biblioteca de fotografia, de fotojornalismo, aprendendo muito sozinho, nunca fiz, assim, faculdade, universidade de foto, sempre fui mais autodidata".

\footnotetext{
${ }^{3}$ Importante fotógrafo brasileiro, respeitado internacionalmente, cujo trabalho é marcado pelo retrato social.
} 


\title{
4.2 Movimento estudantil e coletivos
}

João também construiu suas próprias lutas políticas, engajado no Diretório Central de Estudantes participando de ações, protestos, manifestações, sempre ligado à cultura e em prol de melhorias na universidade. Neste contexto de politização, a fotografia, ao longo do tempo, passou a ser encarada por ele como um instrumento político, de denúncia, capaz de contar histórias que podem gerar ações transformadoras. Um evento que marcou sua ação política na universidade foi uma exposição fotográfica em meio a reivindicações por melhorias no restaurante universitário. João afirmou:

[...] eu tava muito forte no movimento estudantil e [...] a gente começou a fazer uma movida, uma andança ali, um trabalho muito forte com a cultura. [...] Então a gente começou a organizar um festival, a gente fazia protesto, fazia manifestação sempre usando muito a parada da cultura. Teve uma exposição que eu fiz que foi bem legal, que foi na fila do restaurante universitário [...] fiquei uma semana, duas, fotografando o dia a dia do RU e fiz a exposição na fila. E a exposição mostrava as comidas sendo jogadas fora, então a galera antes de comer via as comidas podres indo embora, e foi uma coisa impactante. [...] Foi a partir da vivência no movimento estudantil que eu me envolvi com movimento cultural.

Essas experiências, para além do currículo formal do curso de Design Gráfico, aliadas às participações em festivais de fotografia e trabalhos como fotógrafo freelancer, foram identificadas por João como fundamentais para a sua formação enquanto fotógrafo e ativista.

No caso da fotografia, João afirmou que, na sua visão, os currículos dos cursos de formação têm uma perspectiva instrumental e se restringem aos aspectos técnicos da prática fotográfica, em detrimento da importância de refletir a fotografia enquanto linguagem narrativa. João afirmou que:

\begin{abstract}
[Disciplina de fotografia] até tinha no curso, mas ela não existia, ela era uma disciplina fantasma, ela tava no currículo, mas não existia professor, nem laboratório. Acho que é como as pessoas aprendem muito a fotografia, mesmo hoje. Você tem a formação formal, acho que ela é importante até um certo ponto, mas se você não tem interesse, desejo e busca isso por conta própria, cara, não vai ter universidade ou formação acadêmica que vai te fazer dar conta ou gostar daquilo, entendeu? [...] porque a fotografia é ensinada de uma maneira tecnicista, né? Uma coisa que mais afasta as pessoas [...], é difícil você ver uma formação que coloca a narrativa em primeiro ponto, a fotografia como uma ferramenta de narrativa e que o mais importante é a história.
\end{abstract}

No contexto dessas experiências formativas, João se agregou a um coletivo, ainda em Florianópolis, o Coletivo Cardume, e, enquanto coletivo, se aproximou do Fora do Eixo. Essa relação em rede é característica das relações que se estabelecem entre grupos político/culturais distintos, trocando experiências e, por vezes, promovendo ações coletivas a distância, via internet. João passou a integrar o Fora do Eixo e mudou-se para uma de suas casas coletivas, a Casa FdE São Paulo, como disse:

Entro pro Fora do Eixo e ali estava se começando a se discutir a fundação de uma rede de comunicação independente, que nem tinha nome de Mídia NINJA ainda, 
eu fiz parte disso desde o começo, né? Puxando sempre muito esse lance da fotografia.

O modus operandi de residências coletivas dos integrantes do $\mathrm{FdE}$, em que João é ativo participante, gera diversas oportunidades de interação e de aprendizagem no âmbito do processo formativo. A casa residência é também local de trabalho, seja de construção das narrativas midiáticas que circulam na rede, seja de planejamento das ações coletivas do grupo. A sistemática de reuniões frequentes que se prolongam pela madrugada permite aos integrantes do coletivo, que possuem formações e idades diversas, trocar muitas experiências e saberes, seja presencialmente, seja com os demais integrantes, via rede, que estão localizados em outras regiões do país. A troca de mensagens em grupos temáticos através de um aplicativo de mensagens é intensa, contabilizando centenas de postagens diárias, em geral gerando contribuições objetivas no desenvolvimento de atividades colaborativas compartilhadas entre os integrantes do coletivo.

\subsection{Redes}

A experiência formativa de João, de acordo com a sua percepção, é ampliada durante o próprio fazer ativista como fotógrafo e se revela, por exemplo, nas trocas estabelecidas com pessoas que seguem o seu trabalho nas redes sociais (ver Figura 1). Para ele, o retorno das pessoas, expresso nos comentários, é importante para a compreensão do significado narrativo da sua produção fotográfica: "Acho que é fundamental esse feedback das pessoas em tempo real nas redes, acho que muda completamente a forma não só como você entende o que está produzindo, mas você aprende sobre o que você está falando", afirmou.

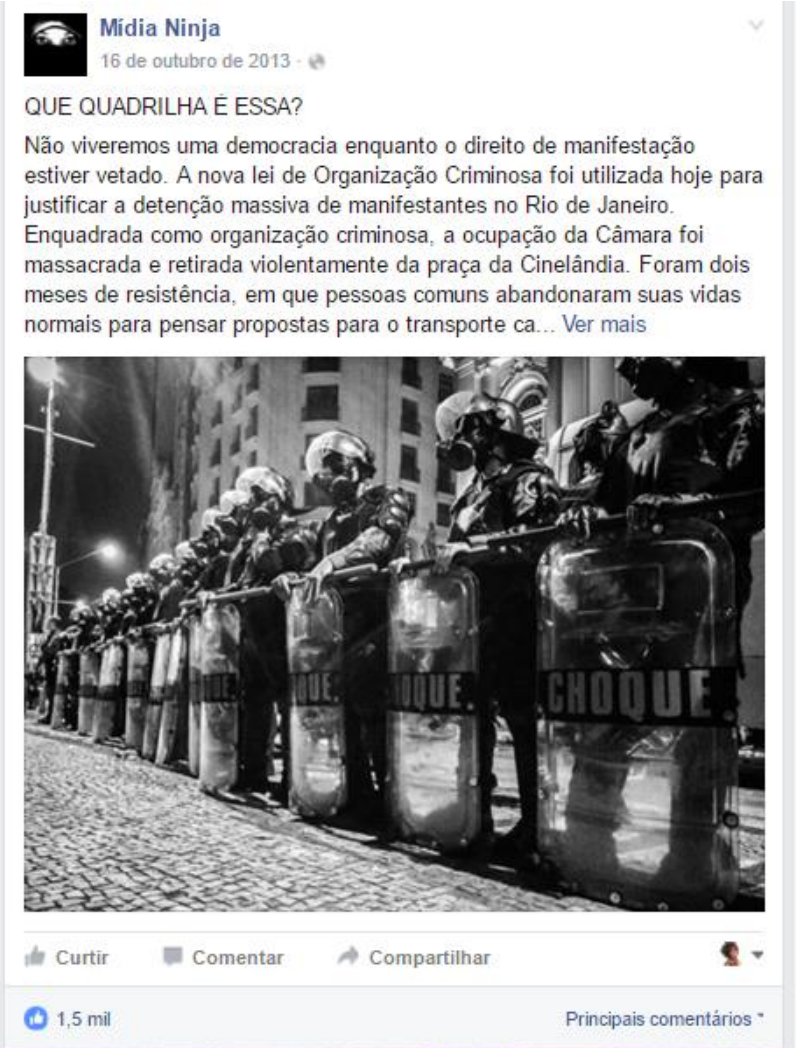

$$
413 \text { Respostas }
$$

Flau Coutinho É inacreditável ler certos comentários nesta página. Tenho certeza que vocês que defendem as açōes policiais não levantaram o rabo da frente do facebook para ir as ruas se manifestar. Eu estive ontem na manifestação apoiando meus amigos que são profess... Ver mais Curtir-Responder - B16-16 de outubro de 2013 às 08:08

B.

Matias Gatti De violência por violência, somos, de uma forma ou de outra, submetidos todos os dias a ela. Ou alguém discorda que seja uma violência saber que um estádio de futebol, que havia sofrido uma grande reforma há seis anos, passa por uma nova reforma, ao cu... Ver mais Curtir-Responder - $B 10$ - 16 de outubro de 2013 às 04:32 - Editado Daniel Sideris Formação de quadrilha é o Cabral e esse Estado corrupto controlado por empreiteiras, ao qual a gente luta contra! Cada um desses policiais que acata as ordens e vai além delas na tentativa de punir manifestantes são mais um membro dessa quadrilha! É, p... Ver mais Curtir-Responder - B8 - 16 de outubro de 2013 ás 03:22 $\hookrightarrow 6$ Respostas

Ronaldo Campos Hoje em São Paulo o saldo foi: manifestantes feridos $0 X$

Amaicias feridos s! Enquanto isso isso em Brasilia nossos politicos dormem como anjos Curtir-Responder - B8-16 de outubro de 2013 às 04:16

2.3. Vitor Barreto Raciocínio de esquerdista sem noção: -. "O Estado é malvado, por isso queremos o Socialismo, onde o Estado cresce e fica dono de tudo." dããäããã

Figura 1: Captura de fotografia e comentários a ela relacionados na página do Mídia NINJA no Facebook 
Como fotógrafo do MN, João revelou em sua fala que no seu trabalho está frequentemente diante de visões divergentes das suas e que esta diversidade de pensamentos expressa nos sites de redes sociais, através dos comentários nas fotos, traz contribuições para a sua atuação como fotógrafo:

\begin{abstract}
A gente lida com um processo de muita diversidade de visão. Não tem uma visão única. E eu acho que a fotografia tem especialmente isso, né? Ela é ambígua por natureza, ela não é uma coisa definitiva, igual ao texto muitas vezes. Ela não afirma uma coisa com começo, meio e fim, às vezes ela é uma experiência estética, às vezes ela é uma vocação, às vezes um cara entende uma foto por um lado e outra foto entende por outro, né? Então a fotografia tem especificamente essa característica de dar margens para interpretações múltiplas. E você observar as interpretações que são feitas por muitas pessoas pelo mundo inteiro, a partir de uma mesma imagem, é um puta de um processo de aprendizado. Tanto sobre o tema quanto sobre o processo fotográfico, quanto sobre a linguagem, quanto sobre o ativismo, visão política.
\end{abstract}

De acordo com João, as diferentes interpretações que as pessoas fazem das suas fotos demonstram múltiplas visões que contribuem para sua aprendizagem sobre fotografia, bem como sobre política e ativismo. Nota-se que as opiniões divergentes e convergentes nas redes sociais podem formar narrativas em torno das fotografias que retratam, por exemplo, o pensamento político de diferentes pessoas. João afirmou que "É [...] uma experiência de aprendizado mesmo: publicar nas redes, ter esse retorno e estar atento a eles". Para ele, a presença do seu trabalho no contexto das redes sociais proporciona experiências de formação que se estabelecem na troca com os interlocutores que comentam suas fotografias e animam sua atuação ativista.

\title{
5 RELAÇÕES ENTRE ATIVISMO E PRÁTICAS COMUNICATIVAS NO CONTEXTO DA CIBERCULTURA
}

O MN foi lançado dois meses antes da eclosão das manifestações nas ruas de todo Brasil em junho de 2013, e aqueles que colaboravam na construção dessa rede já tinham uma trajetória marcada pelo envolvimento em ações ativistas. Diversas ações de comunicação, de caráter mais marcadamente político, já eram desenvolvidas e divulgadas on-line, em meios como a rede social Facebook. De acordo com João,

Antes de 2013 explodir, eu tava, desde 2011, na casa [FdE] de São Paulo, cobrindo praticamente tudo que acontecia na rua, então eu vi todas as marchas, as que tinham quinze pessoas, as que tinham dez mil. A gente fez "Existe Amor em SP", que foi um mega evento que juntou 40,50 mil pessoas numa praça, duas semanas antes da eleição do [prefeito de São Paulo] Haddad, então teve um contexto ali também, onde a gente tava se preparando pra aquilo [...]. Quando explode, o que acontece é que a Mídia NINJA tava preparada, a gente tinha fotógrafo, gente fazendo transmissão ao vivo, gente fazendo redes sociais, gente fazendo design, vídeo, por todo o país, conectado com aquela estrutura das casas coletivas.

Através das várias linguagens, vídeos, fotografia, mensagens, e de uma tecnologia aliada à Internet, o MN construiu uma narrativa para questionar a informação transmitida por grandes grupos de comunicação de massa brasileiros. A fotografia estava entre essas linguagens, usada por 
ativistas e que estavam dispostos a usar sua formação, na arte de fotografar, para construir narrativas alternativas contribuindo, assim, para a luta de uma causa. João afirmou:

[...] eu acho que a gente tava muito qualificado com uma linguagem técnica. Com uma tecnologia de comunicação, e a gente lançou a $\mathrm{MN}$ dois meses antes dos protestos. Ela nunca foi uma mídia de protesto, mas teve uma missão importante no processo de democratização do acesso à informação sobre o que acontecia nas ruas.

A grande importância na democratização da informação se revela, também, na forma como a população brasileira, em geral, recebeu a notícia das manifestações que se espalhavam pelo Brasil. Um episódio que ficou famoso foi uma crônica do jornalista Arnaldo Jabor ${ }^{4}$, no Jornal da Globo, no início dos protestos. Ele descrevia aqueles acontecimentos como ação de vândalos e "rebeldes sem causa" e, de certo modo, desprezava as pautas do protesto. Depois que as redes sociais deram visibilidade a outros ângulos dos fatos, o mesmo jornalista voltou atrás nas suas considerações. As narrativas alternativas construídas em rede coexistiam e disputavam o campo da informação com as grandes mídias, compondo o cenário de ações ciberativistas contra o aumento das tarifas do transporte público, como destacou João:

A gente faz uma puta de uma matéria, um puta de um conteúdo que tem relevância nas redes, ele obriga a imprensa a correr atrás daquilo, entendeu? Então, a gente acaba fazendo um bom trabalho, pendula a narrativa pro lado que a gente acredita, então acho que não se trata só de dar visibilidade ao invisível. Que é uma coisa importante, fundamental, mas também de disputar as grandes narrativas, de mostrar um contraponto, a contra-narrativa dos grandes fatos, das grandes coberturas.

Quando as novas narrativas pendulam as tradicionais e fazem grandes emissoras realinharem sua linha editorial, há uma dimensão educativa na produção desse capital informacional (BENTES, 2009) que se construiu de forma colaborativa e em rede. No caso do MN, faziam circular quase em tempo real imagens e cenas que permitiam a formação de outros olhares, para além daqueles elaborados pela mídia tradicional, que informava, mas também questionava o que estava naturalizado e posto como verdade pela grande mídia, como ressaltou João: "Tinha uma versão oficial dos fatos que foi estraçalhada pela ação em rede do $\mathrm{MN}$ e de vários outros coletivos".

A construção desta nova narrativa "independente" nasceu no contexto da cibercultura, em que práticas ativistas se estruturaram em rede e que romperam com as antigas barreiras da relação tempo e espaço, como é destacado na fala de João: "10 minutos, 5 minutos depois do negócio ter acontecido a gente já tinha publicado, enquanto os fotógrafos de redação [da grande mídia] estavam transmitindo pras agências que iam passar pros jornais, que iam ver as fotos, que eram ultra conservadores na editoria, que iam segurar a informação". A transmissão em rede, realizada pelos ativistas através das câmeras de telefones celulares no seio das manifestações, em tempo real, originou uma nova modalidade de broadcasting que aproximava a audiência dos fatos, relativizando a distância espacial entre os que protoganizavam os eventos e os que assistiam nas telas de seus dispositivos. Ao possibilitar o compartilhamento dos links da transmissão, os

\footnotetext{
${ }^{4}$ Disponível em: https://www.youtube.com/watch?v=luLzhtSYWC4. Acesso em 15 dez 2015.
} 
espectadores também puderam se tornar atores desse broadcasting ao buscarem ativar suas conexões da rede para ampliar a audiência da transmissão on-line dos protestos. Outros participantes dos eventos também tiveram a possibilidade de contribuir com a construção dessas narrativas, enviando suas fotos, por exemplo, que poderiam ser compartilhadas na página on-line do $\mathrm{MN}$.

Essas possibilidades do fazer ativista em rede são atribuídas por João ao processo de migração do paradigma comunicacional massivo para o pós-massivo. Na sua fala, destacou:

O grande lance está no paradigma de migração do modelo de mídia de massa para massa de mídia, onde todo mundo colabora, não tem mais aquela lógica do transmissor da informação e do receptor. Todo mundo é transmissor e todo mundo é receptor. Então, tem uma horizontalidade muito mais colocada, em relação a quem produz e quem distribui, onde a produção colaborativa de milhares de pessoas pra gente é fundamental pra que nosso processo continue existindo [...] em rede, colaborativa, com generosidade, que são valores que pra gente são fundamentais.

Essa narrativa como dimensão educacional e política acontece, também, nas trocas de informação, de saberes e de conhecimentos, na construção de uma rede horizontal de inteligência coletiva que, segundo Lévy (1993 e 2010), é possível, justamente, pelo acesso a uma infinidade de conteúdos digitais e está pautada na "valorização, utilização otimizada e criação de sinergia entre as competências, as imaginações e as sinergias intelectuais, qualquer que seja sua diversidade qualitativa e onde quer que esta se situe" (LÉVY, 2010, p.169). No caso da problemática levantada neste artigo, a construção de uma inteligência coletiva constituiu-se como um ato político que, concorrendo com as grandes e naturalizadas narrativas, contribuíram para uma reflexão sociopolítica mais dinâmica e abrangente.

Nesta perspectiva, no MN, a figura do ciberativista se associa ao que Malini e Antoun (2013) diferenciam como o midialivrista, referindo-se a pessoas que, de dentro dos acontecimentos, como atores desses movimentos, mostram os fatos, geralmente sem edição, ao vivo (através da tecnologia de streaming) com fotografias que cristalizam o momento, sem um comando central sobre as ações de mídia. Assim, chegando a um número muito maior de pessoas, de forma veloz e criando movimento nas redes. A marca autoral desse processo foi destacada por João, que considera a possibilidade de narrar os fatos através da fotografia e suas legendas, de forma autônoma e independente, uma experiência fundamental para a construção do seu ativismo político:

Especificamente na fotografia, a gente teve uma experiência que foi muito radical e ao mesmo tempo definitiva na explosão desse processo, que foi a transmissão de arquivo em tempo real. A gente tinha pego câmeras que tinham wifi embutida alguns meses antes de junho explodir. Então uns 3 ou 5 fotógrafos, se eu não tô enganado, que tinham câmeras com wifi embutido, já transmitiam direto pro celular a foto feita com qualidade na câmera, com lentes boas [...] e o fotógrafo tinha a possibilidade naquele momento, cara, numa página, sei lá, de $200 \mathrm{mil}$ curtidas, que era muita coisa naquela época no NINJA, você publicava uma foto, direto do campo, fazendo a sua legenda. 
Um exemplo das imagens produzidas e compartilhadas por João se encontra representada na Figura 2. João registrou em imagem um momento dos protestos de junho de 2013 , na cidade de São Paulo publicada no aplicativo Instagram pouco tempo depois de capturada, com a ajuda de uma câmera fotográfica com dispositivo de rede wifi.

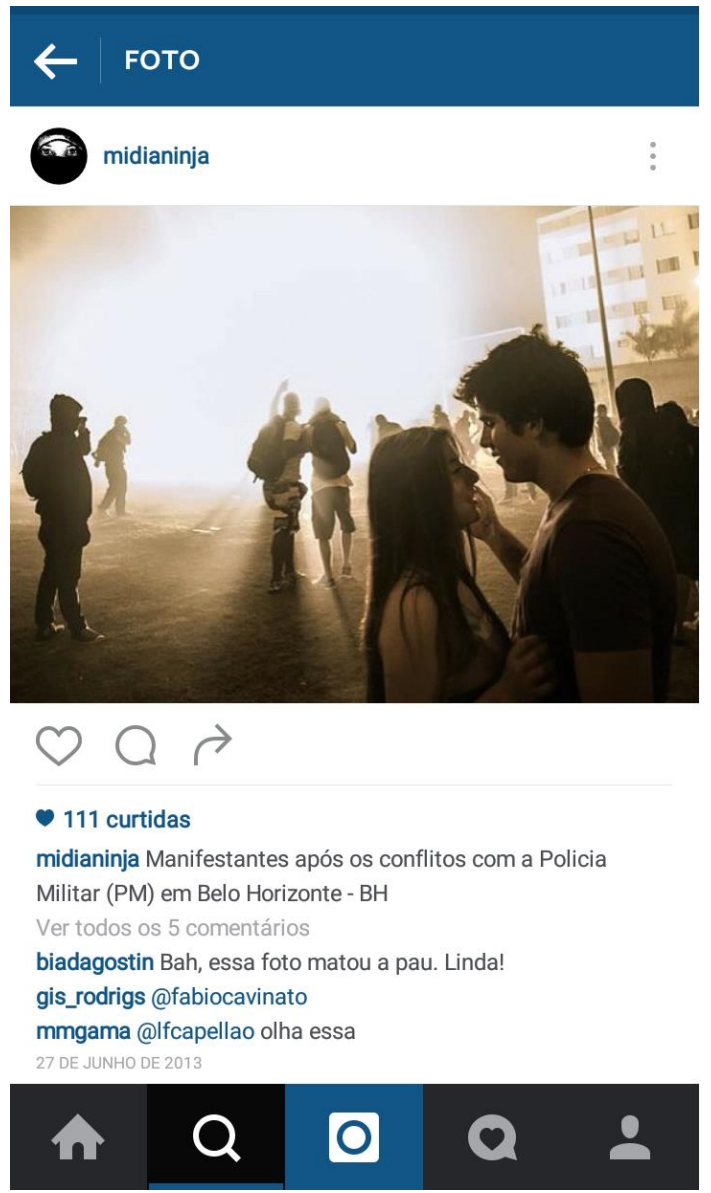

Figura 2: Fotografia capturada durante as manifestações de 2013 na cidade de Belo Horizonte por João

Assim, o midialivrista João atuou como um mediador entre esse acontecimento e os muitos sujeitos que curtiram, compartilharam, reconfiguraram e/ou comentaram aquela fotografia, construindo novos saberes a partir do conteúdo circulante na rede.

\section{CONCLUSÃO}

As práticas comunicacionais da cibercultura proporcionaram um inédito fazer político que deu novas características ao fazer ativista, formando um contexto para a emergência do que chamamos de ciberativismo. Neste contexto, o MN atua ajudando a construir novas narrativas em rede. O presente trabalho buscou compreender como se estruturam as práticas ciberativistas de um integrante do $\mathrm{MN}$ do ponto de vista das trocas comunicacionais e formativas situadas no contexto da cibercultura.

Através da história de João, fotógrafo integrante do $\mathrm{MN}$, identificamos que o fazer ciberativista pode se configurar enquanto um processo político, midiático e formativo. É importante destacar que compreende-se formação em uma perspectiva experiencial, na qual a trajetória dos sujeitos é um elemento estruturante do processo formativo, bem como sua própria transformação e do contexto em que se insere. 
A formação de João revelou que as trajetórias formativas que o conectaram ao ciberativismo envolveram experiências que ocorreram para além dos processos formais de ensino. A família, os coletivos e os festivais compuseram um repertório de trocas que contribuem para a sua formação como fotógrafo e como ativista político. Estas duas dimensões da sua formação pontuam seu fazer ciberativista, na medida em que articulam as possibilidades comunicacionais proporcionadas pela cibercultura com suas ações políticas. Elas são indissociáveis na visão de João.

Identificou-se, através da trajetória de João, que o ativismo em rede vivenciado por ele no $\mathrm{MN}$, mediado pelas práticas comunicacionais pós-massivas próprias da cibercultura, contribui para a construção de narrativas que disputam com as tradicionais narrativas criadas pela mídia de massa. A circulação de conteúdo, fotos e streaming, durante as manifestações de 2013, por exemplo, construíram uma narrativa que possibilitou a ampliação de olhares e leituras sobre aqueles fatos.

Este processo de democratização do acesso à informação, vivenciado nas manifestações de 2013, possibilitou a construção de olhares plurais e diferentes compreensões sobre este acontecimento. Considera-se que estas possibilidades criadas pelo fazer ativista em rede, protagonizado por João, configuram-se em um processo educativo contemporâneo, forjado em uma relação estreita entre o ativismo e as práticas comunicacionais da cibercultura.

Esta experiência pôde demonstrar, ainda, que os processos formativos acontecem para além das estruturas formais de ensino e revela como a cibercultura tem interferido nos processos de aprendizagem dos sujeitos, especialmente no que se refere ao fazer autoral e criativo dos atores dessa rede. Além disso, pode proporcionar ações protagonistas na construção do próprio saber de caráter político, afetivo, cultural, acadêmico, entre outros.

Este estudo se apresenta como uma primeira aproximação do objeto em questão, portanto, possui limitações no que se refere à pesquisa de campo, no contexto original dessas práticas, e ao aprofundamento da trajetória formativa de João. Além disso, toda a experiência aqui relatada foi auto-reportada pelo entrevistado. O aprofundamento deste estudo pretende acompanhar de forma mais sistemática e num maior intervalo de tempo a trajetória formativa de outros ciberativistas, além da relação formativa estabelecida entre o $\mathrm{MN}$ e outros coletivos do midialivirismo.

\section{REFERÊNCIAS BIBLIOGRÁFICAS}

1. BENTES, Ivana. Redes colaborativas e precariado produtivo. online. Revista Periferia. Rio de Janeiro v.1, n.1. p. 53-61. 2009. Disponível em: <http://www.e-publicacoes.uerj.br/index .php/periferia/article/view/3418>. Acesso 10 nov. 2015.

2. BITTENCOURT, Maria Clara Aquino. Narrativas coletivas? Midiatização do ativismo no Mídia Ninja e no RioNaRua. Revista Interin. Curitiba, v. 19. n.1. p. 86-102, jan./jul. 2015.

3. BONDÍA, Jorge Larossa. Notas sobre a experiência e o saber de experiência. Revista Brasileira de Educação. Campinas, n.19, pp. 20-28. Jan/Fev/Mar/Abr. 2002. Disponível em: <http://educa.fcc.org.br/pdf/rbedu/n19/n19a03.pdf>. Acesso em $11 \mathrm{de} \mathrm{fev.} \mathrm{de} 2016$.

4. CARDOSO, Ruth. Movimentos sociais urbanos: balanço crítico. In: SORJ, Bernardo, and ALMEIDA, Maria Hermínia Tavares orgs. Sociedade política no Brasil pós-64 [online]. Rio de Janeiro: Centro, 2008. Disponível em: <http://bit.ly/1W4jCS6> Acesso 03 mai. 2015. 
5. CASTELLS, Manuel. Redes de Indignação e Esperança - Movimentos Sociais na era da Internet, 2013.

6. DI FELICE, Massimo. Ser redes: o formismo digital dos movimentos net-ativistas. Revista Matrizes. São Paulo: n. 2, p. 49-71. 2013.

7. FREIRE, Paulo. Pedagogia da autonomia: saberes necessários à prática educativa. São Paulo: Paz e Terra, 1977.

8. GUIMARÃES JR, Mário José Lopes. Sociabilidade e tecnologia no ciberespaço. In: RIFIOTIS, Theophilos [et al.] (orgs.), Antropologia no ciberespaço. Florianópolis: Ed. da UFSC, 2010.

9. Erro! A referência de hiperlink não é válida.

10. MALINI, Fábio. Mídia Ninja. A disputa pelo poder midiático. [10 de agosto, 2013]. São Paulo: Instituto Humanitas UNISINOS. Entrevista concedida a Patricia Fachin e Ricardo Machado. Disponível em: <http://www.ihu.unisinos.br/entrevistas/522589-o-que-esta-em-jogo-e-adisputa-pelopoder-midiatico-entrevista-especial-com-fabio-luiz-malini-de-lima.> Acesso 30 set. 2015.

11. LEMOS, ANDRE, Cibercultura: tecnologia e vida social na cultura contemporânea. Porto Alegre: Sulina, 2010.

12. LEVY, Pierre. As tecnologias da inteligência: o futuro do pensamento na era da informática. São Paulo: Ed. 34, 1993.

13. Cibercultura. São Paulo: Ed. 34, 2010.

14. MACEDO, Roberto S. Compreender/Mediar a formação: o fundante da educação. Brasília: Liber Livro Editora, 2010.

15. Aprendizagem e formação: aprofundamentos e conexões contemporâneas, Revista Saberes. Paripiranga: v. 1, n. 1. s/p. 2014. Texto online disponível em: <http://faculdadeages.com.br/saberes/wp/wp-content/uploads/2014/07/1.-MacedoAPRENDIZAGEM-E-FORMACA1.pdf> Acesso 03 mai. 2016.

16. MACHADO, Jorge Alberto S. Ativismo em rede e conexões identitárias: novas perspectivas para os movimentos sociais. Sociologias. Porto Alegre, ano 9, no 18, jul./dez. 2007, p. 248-285. Disponível em: <http://seer.ufrgs.br/index.php/sociologias/article/view/5657/3256>. Acesso 28 de out. 2015.

17. MALINI, Fábio e ANTOUN, Henrique. A Internet e a rua - Ciberativismo e mobilização nas redes sociais. Porto Alegre: Sulina, 2013.

18. NASSIF, Luís. Mídia NINJA e Casa Fora do Eixo: a explosão do novo. Texto online disponível em <http://jornalggn.com.br/blog/luisnassif/midia-NINJA-e-casa-fora-do-eixo-a-explosao-donovo>. 2013. Acesso 20 nov. 2015.

19. SAVAZONI, Rodrigo. Os novos bárbaros: a aventura política do Fora do eixo. Rio de Janeiro: Aeroplano, 2014.

20. TORTURRA, Bruno. Jovem jornalista lamenta a crise na grande mídia. 2013. Texto online disponível em: <http://www.brasil247.com/pt/247/midiatech/104363/Jovem-jornalistalamenta-crise-na-grande-m\%C3\%ADdia.htm>. Acesso 10 dez. 2015.

21. VASQUES, Nilton. Mídia NINJA e o jornalismo colaborativo e independente. 2014. Texto online disponível em: <http://www.advivo.com.br/blog/luisnassif/midia-NINJA-e-ojornalismo-colaborativo-eindependente>. Acesso 15 nov. 2015.

22. YIN, Robert. Estudo de caso: planejamento e métodos. 3a ed. Porto Alegre: Bookman, 2005. 